\title{
'Una cosa es el indio y otra cosa es la antropología': Racial and Aural (Dis)Encounters in Cumbia's Current Circulation
}

\author{
JUAN DAVID RUBIO RESTREPO (10
}

\begin{abstract}
This article focuses on the collaboration between Colombian black accordionist Carmelo Torres, the most renown performer of accordion cumbia, and Bogotá-based band Los Toscos, a group of academically trained white-mestizo musicians. Considering Carmelo Torres y Los Toscos as representative of the current state of cumbia's global circulation and in dialogue with the growing corpus of scholarly works on the topic, this article traces how this collaboration has circulated on local, national, and transnational scales and theorizes the different discourses of music, race, and nation that emerge from it. Using recent critiques by thinkers of colour to the work of Deleuze and Guattari, I propose the idea of the racial assemblage and put it in dialogue with contributions to critical geography by Michel-Rolph Trouillot as well as current music scholarship from Latin America and the global north to build a interdisciplinary study that thinks embodied musicking in place.
\end{abstract}

In a small venue in Bogotá, Colombia, a sweaty crowd dances to a mild-tempo cumbia beat. The sound booms across the room, traversing with vibrations that move across the nearly 100 bodies. Heat is generated by the movement commanded by the hypnotic groove emanating from the stage, making the temperature considerably higher than it is outside; a tropical microclimate in the grey Andean plateau. In the venue, mainly filled by white mestizos in their twenties and thirties, there is one body that stands out. On the stage, a few centimetres above the audience, a black accordionist in his sixties commands the ritual as if he were a snake charmer. The accordion interlaces with sounds from a group playing distorted guitar, fuzzed electric bass, and crashing cymbals. A third person sings on the stage. Wearing stylish shades, the singer recites verses with a paused and fluid style. When the chorus kicks-in, the singer suddenly approaches the accordionist. Sharing the microphone momentarily and bringing the house down, together they sing: 'porque una cosa es el indio/y otra cosa es la antropología' ('because the indian is one thing/ and anthropology is another'). ${ }^{1}$ The racially

\footnotetext{
Email: rubior12@gmail.com

I thank Amy Cimini and Gust Burns for their generous feedback on early drafts, the peer-reviewers for their insightful comments, and Alejandro L. Madrid for his editorial work on this article. Different versions were presented at the 63rd annual conference of the Society for Ethnomusicology and at the Global Musics and Musical Communities conference hosted by the Department of Music at the University of California, Los Angeles. The responsibility of the content of this article is my own. Unless otherwise noted, all translations are my own.

1 'La antropología', music and lyrics by Edson Velandia, included on the album Carmelo Torres \& Los Toscos ( ${ }^{*}$ matik matik ${ }^{\star}$ discos). The album is available for purchase at: https://matik-matik.bandcamp.com/album/carmelo-torres-lostoscos. The studio track can be found at: https://youtu.be/iBEkZgzPAcA
} 


\section{Rubio Restrepo 'Una cosa es el indio y otra cosa es la antropología'}

charged words are further complicated by the bodies sounding them. It is December 2015, and the album Carmelo Torres y Los Toscos is being released.

The record, originally containing nine tracks, was initially released in Bogotá, Colombia, by ${ }^{\star}$ matik-matik ${ }^{\star}$ discos in CD and digital formats. Soon enough, it was followed up with vinyl re-issues by the foreign independent labels Names You Can Trust (NYCT) and Galletas Calientes (Hot Cookies). Carmelo Torres is recognized as one of the most important living repositories and performers of accordion cumbia, one of the least-known cumbia styles that was pioneered by Andrés Landero, 'The King of Cumbia'. Los Toscos (The Ruffians) is a group of academically trained musicians out of Bogotá. With a music practice ranging from cumbia to cosmopolitan experimental trends, Los Toscos embody the current eclectic and vibrant local Colombian music scene. Edson Velandia, the singer/songwriter featured on that night in December 2015, could be considered a liminal figure in the collaboration. An outsider of the current local cumbia scene, Velandia has been an outspoken critic of it, often using a sardonic yet insightful tone characteristic of his work. The collaboration between these musicians, from three different backgrounds, signals an important trend in the way in which cumbia is currently being produced, circulated, and consumed in a transnational scale. Moreover, cumbia's entrance to the Euro-American independent market comes hand-in-hand with collaborations such as this.

This (dis)encounter of musicalities and its further global commercialization highlights the importance that acts of mediation continue to have in transnational flows of local musics. Since the turn of the millennium, many of cumbia's regional trends have departed from its local and often racialized status, moving into the Euro-American market. ${ }^{2}$ In this article, I explore the repercussions of these developments focusing on the song 'La antropología' ('Anthropology'), performed by Carmelo Torres y Los Toscos and featuring Edson Velandia. Written and performed by Velandia, the song narrates in a satirical yet insightful style the complexities brought by the revival cumbia movement in Colombia. ${ }^{3}$ I propose

2 Academic literature on cumbia has also risen over the past decade; such efforts have coalesced in Hector Fernández L'Hoeste and Pablo Vila's seminal edited volume Cumbia!: Scenes of a Migrant Latin American Music Genre (Durham, NC: Duke University Press, 2013).

3 Broadly speaking, this movement involved Colombian musicians in the cities turning to local musics. Since the early 1990s, urban musicians have travelled to Colombian peripheral regions - focusing initially on the Atlantic coast and the country's northwest - to study music such as cumbia. I discuss this phenomenon shortly in this article. For more on this topic, see Simón Calle, 'Reinterpreting the Global, Rearticulating the Local: Nueva Música Colombiana, Networks, Circulation, and Affect' (PhD diss., Columbia University, 2012); Jorge Arévalo Mateus and Martín Vejarano, '¿Pa' dónde vas Marioneta? ¿Pa' dónde va la gaita?: La Cumbiamba Eneyé Returns to San Jacinto', in Cumbia!: Scenes of a Migrant Latin American Music Genre, ed. Héctor Fernández L’Hoeste and Pablo Sergio Vila (Durham, NC: Duke University Press, 2013); Hector Fernández L'Hoeste, 'On Whitening and Other Disaffections: The Impact of Tropipop on Colombia's Music Scene', in Music and Youth Culture in Latin America: Identity Construction Processes from New York to Buenos Aires, ed. Pablo Vila (New York: Oxford University Press, 2014); Manuel Enrique Sevilla Peñuela, Juan Sebastián Ochoa Escobar, Carolina Santamaría Delgado, and Carlos Eduardo Cataño Arango, Travesías por la tierra del olvido: modernidad y colombianidad en la música de Carlos Vives y la Provincia (Bogotá, DC: Editorial Pontificia Universidad Javeriana, 2014), and Luis Fernando Valencia Rueda, 'The Alien Musical Brotherhood of the Colombian Andean Plateau: Sound Worlds, Musical Rhetoric, and Musical Meaning in Bogota's Experimental Tropical Psychedelia (1998- 2014)' (PhD diss., Princeton University, 2017). 
the concept of 'racial assemblage' to analyse the complex and fluctuating racial dynamics mobilized by Carmelo Torres y Los Toscos in different geopolitical spaces. I argue that Torres's racialized aurality is systematically mediated by racially liminal and non-racialized agents in order to circulate it in the national and international market. However, rather than erasing Torres's blackness, I suggest that his aural and racial Otherness is simultaneously mediated and desired, thus signalling an aural libidinal economy.

These intricate dynamics of music, race, and space developed from long-lasting histories of difference construction in Colombia that I trace back to the nineteenth century. Focusing in its more immediate antecedent, I consider accordion cumbia vis-à-vis vallenato, another type of Colombian accordion-based music, to explain why, while the latter emerged as 'national music', the former was relegated. After exploring how Carmelo Torres, Los Toscos, and Edson Velandia - both individually and collectively - fit in discourses of race, nation, and transnational circulation, I move to analyse Torres's collaboration with British musician/ actor Johnny Flynn. Triggered by his work with Los Toscos, Torres's project with Flynn sponsored by the BBC - marks another stage of cumbia's circulation in the global north.

Re-evaluations of cumbia's racialized and class-based connotations have been theorized by authors such as Alejandro L. Madrid on the US-México border, and Fernández L'Hoeste (2014) in Colombia. ${ }^{4}$ Noting how regional cumbia trends have transitioned from workingclass practices into cultural commodities that are consumed by middle- and upper-class sectors of society, both authors have traced changes in how and, most importantly, who produces this music has effectively led to a sociopolitical shift in traditional associations between race, class, and music. Similarly, focusing on Buenos Aires, Argentina, and Perú respectively, Baker and Tucker have offered pungent critiques to previous positions that have exalted cumbia as a potential utopian aural public space of social cohesion. ${ }^{5}$ Although they point out particular nuances in these different contexts, these texts signal a consistent transformation of cumbia throughout America since the turn of the millennium.

4 Alejandro L. Madrid, Nor-tec rifa!: Electronic Dance Music from Tijuana to the World (New York: Oxford University Press, 2008); Fernández L'Hoeste, 'The Impact of Tropipop on Colombia's Music Scene'.

5 Identifying a 'post-digital ethos' in cumbia practices in Buenos Aires since the turn of the millennium, Geoffrey Baker argues that increased access to digital technologies by the local working classes brought a rise of cumbia produced entirely through digital means by these populations. Instead of bridging the race-class gap, accessibility to digitalism decreased the cultural capital once indexed to electronic music among middle- and upper-class circles, thus reifying class differences. In the case of Peru, Joshua Tucker criticizes views by scholars such as anthropologist José Matos Mar. In the 1980s, and noticing that by then the Andean migrants who flooded Lima since the mid-twentieth century were established enough to become an important sociopolitical force in a historical white-mestizo city, Matos Mar argued that an era of socioeconomic inclusion and ethnic cohesion was imminent. For him, a local variant of cumbia called chicha illustrated this transition. Writing from the 2010s, Tucker critiques this position and shows how cumbia's evolution in the 1990s and the recent transnational boom of chicha reifies and fetishize difference. Geoffrey Baker, “"Digital indigestion": Cumbia, Class and a Post-Digital Ethos in Buenos Aires', Popular Music 34/2 (2015); Joshua Tucker, 'From the World of the Poor to the Beaches of Eisha: Chicha, Cumbia, and the Search for a Popular Subject in Peru', in Cumbia!: Scenes of a Migrant Latin American Music Genre, ed. Héctor Fernández L'Hoeste and Pablo Sergio Vila (Durham, NC: Duke University Press, 2013). 
In general, ideas around cumbia's mobility across social strata continue to be prevalent in academic literature. Unlike most of these case studies, where regional practices are picked up and 'revamped' by middle- and upper-class musicians, ${ }^{6}$ Carmelo Torres y Los Toscos signals a different trend (particularly in Colombia): collaborative projects that bring together racialized - most of whom are from a rural background - and academically trained white-mestizo urban musicians. This complicates ideas of "whitening" that have become dominant tropes to theorize cumbia's circulation throughout the twentieth century. In contrast to these views, I argue that in this particular case it is precisely the very alterity of the racialized 'Other' and their aurality that the white-mestizo musicians desire; a desire that is sustained throughout the entire chain of its consumption.

This drastic shift in how race is perceived and lived as well as its relation to musicking is directly linked to radical discursive changes that were brought by the Colombian 1991 constitution. More specifically, it is related to a shift from a homogenizing state discourse of mestizaje that publicly exalted racial mixing but that concealed a systematic process of ethnic (and even biological) whitening, to one in which multiculturalism and cultural difference became assets. ${ }^{8}$ While under the mestizo social order musics from distinct Afro-Indigenous origins had to endure systematic processes of whitening to be nationally circulated and consumed, ${ }^{9}$ in the era of multiculturalism the state has placed value on 'folk' practices, exploiting its cultural and financial capital. It is in this sociopolitical juncture that I place Carmelo Torres y Los Toscos feat. Edson Velandia. The (dis)encounter among these musicians constitute a microcosm of how national subjects are working with and against the multicultural moment. Thus,

6 For instance, in his study of Tijuana-based Nor-tec Collective, Alejandro L. Madrid traces how regional cumbia norteña was appropriated and instrumentalized by Nor-tec's members, most of whom had a background not in Mexican regional music but in Electronic Dance Music. Fernández L'Hoeste focuses on the emergence of 'tropipop' in Colombia. A short-lived trend that devolved from the sound pioneered by artists such as Carlos Vives, tropipop was primarily performed by wealthy youths who attended exclusive high schools. Madrid, Nor-tec rifa; Fernández L'Hoeste, 'The Impact of Tropipop on Colombia's Music Scene'.

7 In the Latin American musical context, this is a concept that has been developed by race thinkers such as Peter Wade and advanced by music scholars such as Oscar Hernández Salgar. Whitening is a complex idea and for my purposes it suffices to define it as the process through which certain music practices are altered to fit a racially whiter imaginary by incorporating elements derived from the European concert music canon and, later on, Anglo popular music. Instrumentation, forms, harmonic structures, and in film and television mise en scène and any of the elements that comprise 'musicking' may take part in whitening processes. Peter Wade, Race \& Nation: Música Tropical in Colombia (Chicago: University of Chicago Press, 2000); Oscar Hernández Salgar ('Colonialidad y postcolonialidad musical en Colombia', Latin American Music Review 28/2 (2007).

8 While in Colombia the multicultural discourse triggered by the promulgation of the 1991 constitution did signal a discursive shift, as Eduardo Restrepo, Ernesto Schwartz-Marín, and Roosbelinda Cárdenas have argued, this does not imply a fracture, but rather a different stage of the mestizo social order. Eduardo Restrepo, Ernesto Schwartz-Marín, and Roosbelinda Cárdenas, 'Nation and Difference in the Genetic Imagination of Colombia', in Mestizo Genomics: Race Mixture, Nation, and Science in Latin America, ed. Peter Wade, Carlos López-Beltrán, Eduardo Restrepo, and Ricardo Ventura Santos (Durham, NC: Duke University Press, 2014).

9 Wade, Race \& Nation. 
more than a mere collaboration, I think of the album produced by Carmelo Torres, Los Toscos, and Edson Velandia as a 'racial assemblage'. ${ }^{10}$

I expand on Weheliye's intervention to Gilles Deleuze and Félix Guattari's seminal assemblage concept by putting it in dialogue with Rolph-Michel Trouillot's ${ }^{11}$ contributions to critical geography. Such an approach allows for a theorization that considers music production and circulation at the intersection of race and geopolitics. Tracing how a racial assemblage such as Carmelo Torres y Los Toscos travels across geographical scales implies taking up a theoretical approach that accounts for its fluidity and the ever-changing nature that emerges when sound, race, and place intersect. While this article is structured following geographical scales that go from the local to the transnational, this does not imply a hierarchical teleological relation. Rather, it seeks to illustrate the many shapes this assemblage takes.

As an active member of the Bogotá music scene for the last fifteen or more years, my perspective on these processes of transculturation derives from witnessing firsthand the emergence of the underground cumbia scene in the city and later seeing its success abroad. While I am not a part of this movement, many of its members have been and continue to be close collaborators of mine, including several who are part of this case study. Unlike many cumbia trends over the second half of the twentieth century in which music practices endured systematic processes of whitening in order to make the music more palatable to the middle-class consumer, trends at the turn of the millennium brought a renewed interest for these racialized sounds.

\section{From the local to the national: the struggle for the aural national subject}

In Colombia, a country that is as miscegenated as it is segregated, the fact that musics from Afro-Indigenous origins such as cumbia and vallenato were annexed into the national discourse is perplexing to say the least. There, the relation between music, race, geography, and nation has been a complex one. As Nancy Appelbaum ${ }^{12}$ argues, Colombia has been constructed as a 'country of regions' since its very inception. Throughout the nineteenth century, when criollo elites were leading the newly independent Latin American nations through their early stages of republicanism, 'They were concerned with the international image of their nations in a transatlantic context that increasingly equated modernity with whiteness. [At the same time] They were reluctant to completely reject the racially structured labor systems upon which their own fragile fortunes depended. ${ }^{, 3}$ Colombian elites, balancing between maintaining racial difference and promulgating homogeneity, considered discourses about mestizaje (race mixture) an asset in the nation-building project, even as they clung to their whiteness.

10 Alexander G. Weheliye, Habeas Viscus: Racializing Assemblages, Biopolitics, and Black Feminist Theories of the Human (Durham, NC: Duke University Press, 2014).

11 Michel-Rolph Trouillot, Peasants and Capital: Dominica in the World Economy (Baltimore: Johns Hopkins University Press, 1998).

12 Nancy P. Appelbaum, Mapping the Country of Regions: The Chorographic Commission of Nineteenth-Century Colombia (Chapel Hill: University of North Carolina Press, 2016).

13 Appelbaum, Mapping the Country of Regions, 18. 
Such contradictory narratives were further complicated by Colombia's segmented territory as well as its widely diverse population. Equating physiological 'types' with geographical place, nineteenth-century intellectuals 'emphasized the importance of the natural environment in shaping the character of each regional society and population'. ${ }^{14}$ Throughout the twentieth century, discursive formations of race and nation have been widely dynamic in Colombia. From intellectuals in the first half of the century advocating for eugenics as a form of state policy $^{15}$ to the multicultural moment in which I situate my study. During these epistemic shifts, the race-region relation has sedimented in the national imaginary. Broadly speaking and following the country's 'natural regions' discourse - the Andean plateau, and particularly the major urban centres such as Bogotá and Medellín, is rendered as mostly white-mestizo, with the northwestern Atlantic coast labelled as tri-ethnic (white, African, and Indigenous) and miscegenated, with its rural areas being predominantly Afro-Indigenous and racialized. Along with these differences are a series of attributes having to do with sexuality, work ethic, family values, etc. that are indexed to each regional 'type'. In the national imaginary, this has effectively led to the construction of the Andean urban white mestizo as the normative subject, with the peripheral coastal subject as an Other. ${ }^{16}$

As a result, a long-standing relation of alterity runs deep between the Andean metropoles (el interior, or interior region) and the Atlantic coast and its peripheries (la costa). This relation of Otherness is key to better understand the national circulation of coastal music and its eventual rise to national popularity. The consumption of coastal musics in the interior, I argue, has been historically traversed by an unresolved - yet not oxymoronic - friction between Otherness and desire. While most literature on the topic has focused on coastal music that became a 'national sound', I take a different approach to this issue. I focus not on the musics that made it into the canon, but on the ones that did not, the residual, so to speak. Furthermore, I trace how these processes of inclusion/exclusion continue to develop in contemporary Colombia. More specifically, I examine how local musicians from different backgrounds such as Carmelo Torres, Los Toscos, and Edson Velandia interact with such discourses. However, first it is important to introduce the musicians.

As mentioned, Carmelo Torres is Colombia's most renowned performer of accordion cumbia. He was raised in the rural San Jacinto region, a predominantly miscegenated area in the Colombian Northwest with a dense Afro-Indigenous population and that is considered one of the places where cumbia's origins have been traced. Currently in his sixties and from a peasant

14 Appelbaum, Mapping the Country of Regions, 18.

15 Jorge Uribe Vergara, 'Sociología biológica, eugenesia y biotipología en Colombia y Argentina (1918-1939)', in Genealogías de la colombianidad: formaciones discursivas ytecnologías de gobierno en los siglos XIX y XX, ed. Castro-Gómez Santiago and Eduardo Restrepo (Bogotá: Pontificia Universidad Javeriana, 2008).

16 On this relation, Wade mentions: 'compared to the highland interior, Costeño cultural practice is [thought of as] less inhibited, more open, more emotional, more sincere, more fun, more "sexy" (in the various modern connotations of that term), and also more superstitious, more magical, less Europeanized, less bound by the constraints of scientific and bureaucratic rationality, and thus more liable to the eruption of the bizarre... Costeño men are said, by themselves and others, to be womanizers; Costeño women may be thought of by non-Costeños as sexually loose ... These all create a picture of male-female relations and sexuality which are less restricted by Catholic piety than in the interior' (Music, Race \& Nation, 44). 
background, Torres has been performing professionally since age sixteen. ${ }^{17}$ Over the last decade, he has been touring in America, Europe, and Asia with his own band, mostly performing traditional tunes by composers such as Adolfo Pacheco and Toño Fernández and carrying the legacy of Andrés Landero, otherwise known as 'The King of Cumbia'. Torres met Landero in 1975 and eventually became his pupil. After Landero's passing in 2000, Torres was anointed as his direct successor and one of the main keepers of accordion cumbia - a style recognized as Landero's - a legacy that Torres assumes with a sense of responsibility. ${ }^{18}$ Descendent of a long-line of gaiteros (the person who pays the flute-like gaita, one of the iconic instruments of Colombian coastal cumbia $)^{19}$ Landero himself was part of the legendary Los Gaiteros de San Jacinto. Eventually, he would start adapting the gaita melodies to the accordion as well as the overall style of the indigenous instrument to the European one.

Los Toscos is a Bogotá-based collective formed by bassist Santiago Botero, guitarist Enrique Mendoza, and producer Benjamin Calais. Individually, the band's members are involved in projects that include jazz, noise, multimedia collaboration, experimental music, and improvisation. Both Botero and Mendoza hold graduate degrees in music and teach at local universities. The French-born Calais also mixes records and runs the local venue ${ }^{\star}$ matik-matik ${ }^{\star}$, a node for the local underground scene and an important space for the way this racial assemblage has developed, as I elaborate below. Los Toscos is conceived as an eclectic project reflecting its members' diverse influences. They function as a side band of sorts, inviting artists from different backgrounds to perform and record. Their first album featured New York-based saxophonist Tony Malaby, an active figure in the 'downtown avant-jazz' scene. Finally, Edson Velandia is one of the most provocative figures in the Colombian independent music scene. A performer/composer, his body of work includes several solo albums, a CD of children's songs, tunes denouncing state violence, big band pieces that he conducts using a

17 Revista Arcadia, 'Carmelo Torres y el futuro de la cumbia'. 8 February 2018. www. revistaarcadia.com/impresa/musica/ articulo/entrevista-con-carmelo-torres-el-heredero-de-la-cumbia-sabanera-de-andres-landeros/68043.

18 The sound Landero pioneered goes by different names: cumbia de acordeón (accordion cumbia); cumbia sabanera (savannah cumbia); and simply cumbia, among others. In the interest of clarity, throughout the article I use accordion cumbia. The sabanero adjective alludes to a geographical provenance placing this music in the sabanas (savannahs) of the San Jancinto and Montes de María, Bolivar, region, located in the Bolivar and Sucre states in the Colombian northeast. While Landero's music remains unknown to the bulk of Colombians, he holds an iconic status around the world among cumbia connoisseurs. He is a fundamental pillar in the cumbia subculture in Monterrey, Mexico (Juan David Rubio Restrepo, 'Cumbias y rebajadas: Aurality, Race, and Class in Monterrey's "Colombia” Culture', in Scattered Musics, ed. Martha Chew Sánchez and David Henderson (Jackson, MI: University Press of Mississippi, forthcoming)), highly regarded by Argentinian cumbia villera artists such as Pablo Lescano, and even by The Clash's Joe Strummer, who was outspoken about his passion for Landero. Mario Galeano has a short piece on this uncanny relation. Mario Galeano ('Guacharaca Calling', Noisey, VICE, 2015, https://noisey.vice. com/es_co/article/rbzbba/guacharaca-calling).

19 While the gaita remains the most identifiable instrument behind cumbia in the Colombian imaginary, according to Federico Ochoa Escobar and Juan Sebastián Ochoa, this relation was constructed over the second half of the twentieth century. Federico Ochoa Escobar, 'Las investigaciones sobre la caña de millo o pito atravesao', Cuadernos de Musica, Artes Visuales y Artes Escenicas 7/2 (2012) and El libro de las gaitas largas (Bogotá: Editorial Pontificia Universidad Javeriana, 2013); Juan Sebastián Ochoa, 'La cumbia en Colombia: Invención de una tradición', Revista Musical Chilena 70/ 226 (2016). 
machete in lieu of a baton, and even an opera about a man that is constipated because his chamber pot was stolen. ${ }^{20}$

While Andrés Landero was at the centre of a group of accordion musics that eventually became a symbol of national aural identity, he was paradoxically shunned from the canon. Towards the second half of the twentieth century, cumbia in its more 'traditional' iterations and other types of accordion music from these regions were interpellated by political and intellectual elites and eventually annexed to nationalistic discourses. ${ }^{21}$ However, Landero's accordion cumbia fell through the cracks of this sanctioned national sound. Ana María Ochoa Gautier calls this 'entextualizing', that is, the process through which - in this case a particular group of accordion music from the region, eventually grouped under the genre denomination vallenato, 'came to be mobilized as a valid folk regional music by a political and artistic elite within the Caribbean'. ${ }^{22}$

Ochoa Gautier echoes Peter Wade in arguing that curating, exalting, and promoting these musics was a process advanced by intellectual and political interests, predominantly white mestizo elites. Aside high-ranking government officers, literary luminaries such as Colombian Literature Noble Prize winner Gabriel García Márquez were instrumental in consolidating the national status of vallenato. The fact that García Márquez was one of the genre's most important chroniclers in his early days as a journalist, and that he further mythologized vallenato in his seminal novel A Hundred Years of Solitude, proved fundamental in transforming the emerging genre from regional music practice into a national soundtrack.

However, in this process, a great deal of accordion musics that were happening in the region were left aside. This is where Landero and his accordion cumbia fit in - or better put, where it did not. For, as Ochoa Gautier mentions, 'with the visualisation of vallenato, the use of the accordion in genres such as cumbia became practically invisible (or inaudible) in the country' $^{23}$ It is important to consider the racial undertones of this exclusion. Peter Wade points out how, for example, besides García Márquez and the regional political elite, there was another crucial agent in the canonization process: the composer Rafael Escalona. ${ }^{24}$ Born

20 One of Velandia's most compelling songs is 'La muerte de Jaime Garzón' ('Jaime Garzón’s Death') included in his album El karateka (a version of the song is available at: https://vimeo.com/111250579). It has been mentioned that far-right circles inside the Colombian government (including the military and intelligence agencies) and paramilitary groups under the command of Carlos Castaño conspired to assassinate comedian Garzón.

21 I use this word in the Althusserian sense. In his seminal essay 'Ideology and Ideological State Apparatuses: Notes towards an Investigation', post-Marxist thinker Louis Athusser uses the word 'interpellate' to describe the process through which individuals are made into subjects and thus annexed into the state via - what he calls - Ideological State Apparatuses. He writes: 'all ideology hails or interpellates concrete individuals as concrete subjects'. I find Althusser's concept a productive one to think how music practices are indexed into nation discourses. Louis Athusser, 'Ideology and Ideological State Apparatuses: Notes towards an Investigation', in Lenin and Philosophy, and Other Essays, with introduction by Fredric Jameson, trans. Ben Brewst (New York: Monthly Review Press, 2001), 117.

22 Ana María Ochoa Gautier, 'García Márquez, Macondismo, and the Soundscapes of Vallenato', Popular Music 24/2 (2005), 210

23 Ochoa Gautier, 'García Márquez, Macondismo, and the Soundscapes of Vallenato', 215.

24 Wade, Race \& Nation, 63. 
into a well-to-do military family, Escalona was not the prototypical rural minstrel. A lighterskinned, educated man that sneaked away from his upper-class setting to witness the racialized accordion parrandas (parties), Escalona eventually became a fundamental composer of the vallenato songbook.

There are several reasons why vallenato did not spread through Latin America - and the world - as cumbia did. On the one hand, one motive has to do with timing. Colombian-made cumbia hit the continent as early as the 1940s when the Latin American music industry was gaining momentum, ${ }^{25}$ while vallenato emerged as a cohesive music practice and marketable genre in the 1970s. On the other hand, an important part of cumbia's transnational success had to do with its musical simplicity. In its most basic expression, cumbia's rhythmic structure is both distinctive and malleable. It allows for experimentation and mixture while retaining its sonic character. This was not the case with vallenato which, after it was standardized, was left with a set of very specific and complex music structures that are hard to learn apart from their place of origin. ${ }^{26}$ While Landero's music practice wandered across many of the accordion styles present in the region, he did not adhere to the few that were sanctioned by local elites. Instead, he focused on developing and expanding the cumbia repertoire he pioneered, a unique and personal sound of which he was, if not the only, perhaps the main exponent.

The fact that Landero was left outside the vallenato canon made accordion cumbia unintelligible and inaudible in the national scope. Landero participated several times in the Festival de la Leyenda Vallenata, the most prestigious accordion music festival in Colombia, with no luck. In other words, the mythical 'King of Cumbia' was never crowned on his own turf. While vallenato went on to become one of the most consumed musics in Colombia - even resisting the reggaeton cyclone - Landero and his musical legacy continues to be virtually unknown by the bulk of Colombians. Perhaps even more telling is the fact that Peter Wade's book, still the 'to-go' text on music of the Colombian Caribbean due to its theoretical insightfulness and robust archival and ethnographic work, does not even mention Landero. A misfit when it comes to nationalist discourses, Landero's idiosyncratic style,

25 For instance, cumbia by several Colombian performers was recorded and distributed in Argentina as early the 1940s (Wade, Music, Race \& Nation, 96). Colombian singer Luis Carlos Meyer recorded porros and cumbias in Mexico with local bands in the same decade. The transnational circulation of this music lasted well into the 1970 s with bands such as Los Corraleros de Majagual, among many others. It must be noted that this was by no means a 'one way street'. Cumbias produced outside Colombia made it back. Such is the case of the Peruvian cumbia repertoire that was covered in the 1970s by Medellín-based bands such as Los Hispanos and Los Graduados.

26 I am referring to what is called the 'cuatro aires' of vallenato. Four distinct styles with specific musical structures that make the vallenato canon; namely, son, merengue, puya, and paseo. While vallenato continues to be consumed and performed primarily by Colombians, an important - and perhaps unique - exception to this is the colombia culture in Monterrey, México; see José Juan Olvera Gudiño, Colombianos en Monterrey: origen de un gusto musical y su papel en la construcción de una identidad social (Monterrey, NL, Mexico: Consejo para la Cultura y las Artes de Nuevo León); Darío Blanco Arboleda, Los colombias y la cumbia en Monterrey: identidad, subalternidad y mundos de vida entre inmigrantes urbanos populares (San Nicolás de los Garza, NL, México: Facultad de Filosofía y Letras, Universidad Autónoma de Nuevo León, 2014); and Rubio Restrepo, 'Cumbias y Rebajadas' in Monterrey’s “colombia” Culture’. 


\section{Rubio Restrepo 'Una cosa es el indio y otra cosa es la antropología'}

now in the hands of his pupil Carmelo Torres, was eventually picked up by a new generation of Colombian musicians.

\section{Scaling 'La antropología'}

In order to trace how the collaboration between Carmelo Torres, Los Toscos, and Edson Velandia circulates in different geographical spaces, I use the idea of 'scales'. By scale, I mean the ways in which this aural and racial assemblage is rendered locally, nationally, and transnationally. Pioneered by Haitian anthropologist Michel-Rolph Trouillot, this approach affords thinking about not just the ways in which capitalism subsumes life, but how specific agents fit in such a scheme and, in my case, how they fit in the distributed and dynamic network of agents involved in music's circulation. By focusing on the specific track 'La antropología', I am simultaneously performing a 'microlevel study', a methodology also developed by Trouillot. He writes: 'The shift to a microlevel implies the acknowledgment of the individual's capacity to contribute to the historical process; to generate, so to speak, "more history" than the history of which he or she is the product. ${ }^{27}$ I elaborate on Trouillot's work not just as a way to emphasis human agency - over, for instance, the world music industry - but also as decolonial ethos, following the production-consumption chain from the bottom up. ${ }^{28}$

By scaling Carmelo Torres y Los Toscos, I underline the long-lasting processes of difference construction that have produced these geographical categories, the genealogies of racialization that have sedimented them, and their inextricable relation with music practices. But also, I highlight the potentiality that the circulation of this music has in mobilizing - in the words of ethnic studies scholar Kirstie Dorr - 'modes of political dissent'. ${ }^{29}$ Trouillot refers to the different scales a study can engage with as 'units'. While he did not consider the human body as a unit, his emphasis on human agency nonetheless foregrounded it. ${ }^{30}$ If, as critical geographers have argued, space is relational and ideologically produced, ${ }^{31}$ then it

27 Trouillot, Peasants and Capital, 17.

28 More than a methodological approach, Trouillot's theorization signals a decolonial ethos. Pushing against worldsystems theories pioneered by Euro-American thinkers such as Immanuel Wallerstein that dominated the social sciences in the 1980s and 1990s, Trouillot's idea of the microlevel gave priority to specific marginalized agents such as peasants in Dominica over macro, universalist, Eurocentric approaches. By doing so, Trouillot was proposing a post-Marxist approach 'from the bottom-up'. Trouillot, Peasants and Capital.

29 Kirstie Dorr has furthered the project of thinking race through sound and space, fostering a dialogue between sound studies and critical geography. In her study of transnational flows of South American music, she conceives space as socially and ideologically constructed and relational. Dorr thinks of place and its relation to sound as a 'an ensemble of social relations given meaning through geopolitical designation'. Kirstie Dorr, On Site, In Sound: Performance Geographies in América Latina (Durham, NC: Duke University Press, 2018), 11.

30 Anthropologist Vanessa Agard-Jones has elaborated on this, incorporating the (human) body to Trouillot's schema. Vanessa Agard-Jones, 'Bodies in the System', Small Axe: A Journal of Criticism 42 (2013).

31 Following Katherine McKittrick and Lind Peake, Dorr argues: 'racialization, gendering, and class formation are spatialized practices of material emplacement and ideological abstraction that encompass no less than what Ruth Wilson Gilmore has described as the "death dealing displacement of difference into hierarchies that organize relations" within and between contested sites, scales, and landscapes' (On Site, In Sound, 10). 
follows that the body is the fundamental geographical unit. Thus, while I theorize Carmelo Torres $y$ Los Toscos across different geographical spaces, I also conceive the body an integral part of this scheme. More specifically, I am interested on how the racialized body circulates across these scales. Importantly, I suggest that Carmelo Torres y Los Toscos is not just a body, but also a collection of differently racialized bodies; what I am referring to as a racial assemblage.

\section{Racial and racializing assemblages: cumbia beyond whitening}

Deleuze and Guattari theorize the assemblage concept in their different works Chaosmosis, ${ }^{32}$ A Thousand Plateaus, ${ }^{33}$ and The Machinic Unconscious. ${ }^{34}$ Like many Eurocentric thinkers, their intellectual genealogy does not foreground thinking about or through race. ${ }^{35}$ However, critical race theorists have critiqued Deleuze and Guattari's work and have elaborated on their ideas, advancing a decolonial project that, far from discarding ideas and authors deemed as Eurocentric, engage critically and productively with them. African American Studies scholar Alexander Weheliye, for example, has built on the work of black feminist thinkers Hortense Spillers and Sylvia Wynter to offer substantial correctives that turn Deleuze and Guattari's notion of the assemblage towards critical race studies. ${ }^{36}$ Weheliye explains that assemblages (arrangement in English) 'constitute continuously shifting relational totalities comprised of spasmodic networks between different entities (content) and their articulation within "acts and statements" (expression)'. ${ }^{37}$ Weheliye prefers 'racializing assemblages' to racial categories because, he argues, the former 'construes race not as a biological or cultural classification but as a set of sociopolitical processes that discipline humanity into full humans, not-quite-humans, and nonhumans'. ${ }^{38}$ Racializing assemblages aim to expose and dis-articulate the networks of ideas and flows of capital that construct and maintain (racial) difference. At the interception of financial and cultural capital, the world music industry capitalizes on alterity as it reifies it, and further fetishizes difference by commodifying it.

32 Félix Guattari, Chaosmosis: An Ethico-Aesthetic Paradigm (Sydney: Power Publications, 1995).

33 Gilles Deleuze, Brian Massumi, and Félix Guattari, A Thousand Plateaus: Capitalism and Schizophrenia (Minneapolis: University of Minnesota Press, 2003).

34 Félix Guattari, The Machinic Unconscious:Essays in Schizoanalysis (Cambridge, MA: Semiotext(e), 2011).

35 For further discussion on Eurocentrism and race see Sylvia Wynter, 'Unsettling the Coloniality of Being/Power/Truth/ Freedom: Towards the Human, After Man, Its Overrepresentation - An Argument'. CR: The New Centennial Review 3/ 3 (2004); Anibal Quijano and Michael Ennis, 'Coloniality of Power, Eurocentrism, and Latin America', Nepantla: Views from South 1/3 (2000); Nelson Maldonado-Torres, 'Post-continental Philosophy: Its Definition, Contours, and Fundamental Source', Worlds \& Knowledges Otherwise 1/2 (2006).

36 More specifically, Weheliye critically engages Foucault and Agambem's idea of biopolitics. Having become a standard concept to discuss the classification of human life, Weheliye elaborates on Spillers's and Wynter's thought to perform a substantial intervention - a 'corrective' as he calls it - to biopolitics, arguing that in its Eurocentric notion, the concept falls short as a conceptual tool to discuss and disassemble race as the marker of difference rendering bodies as 'fullhuman, not-quite-humans, and nonhumans'. Weheliye, Habeas Viscus. 
By putting Weheliye and Trouillot in dialogue, I propose two analytical trajectories: 1) a racial assemblage that groups together bodies that have been subjected to different racializing assemblages; and 2) attention to the different scales at which these assemblages function. While each of the agents that form Carmelo Torres y Los Toscos feat. Edson Velandia embody a particular racializing assemblage, once they are circulated as a collaboration, that collaboration itself becomes an assemblage. This secondary assemblage formed in their collaboration is what I am referring to when I use the concept of racial assemblage. Carmelo's black body is rendered differently in the regional, the national, and the transnational context. The same goes for each band member and Velandia. As I have shown, at the local and national scale, racial formations are concomitant with the fact that Colombia has been historically constructed as a 'country of regions ${ }^{39}$ in which difference and geography have been intertwined since the colonial era. However, once it is circulated transnationally, the assemblage's meaning fluctuates. Place illustrates, in this case, the spasmodic quality of racial assemblages as they traverse different geopolitical spaces. In other words, place conditions how Carmelo Torres y Los Toscos feat. Edson Velandia functions as a racial assemblage. While Weheliye's racializing assemblages prioritize ideology and ontology, I ask how race is rendered through the body and query how entities embodying different racial formations interact and are rendered as a unit in different geopolitical scales.

Studying Carmelo Torres y Los Toscos as an assemblage attends to how meaning emerges from the relation these bodies hold between each other. Meaning and content are products of the relational quality between the performers as well as the ways in which this relation is circulated and mediated across geographical scales. Meaning fluctuates in different spaces; how racializing assemblages come together must be contingent to the geopolitical location from which they are rendered. Thus, as I elaborate below, Carmelo Torres's racialized body and by extension his aurality - is circulated and instrumentalized differently across scales. Los Toscos, on the other hand, represent what I call liminal racial subjects. Read from a transnational scale, Los Toscos constitute a racial space of 'in-betweenness' that mediates Carmelo Torres's aural Otherness, thus rendering it audible. Their urban subjectivity and globalized musicality makes them a mediating agent in the circulation process. Finally, I consider Velandia a meta-narrator, a critical voice that narrates the (dis)encounter from the inside with an incisive and sardonic tone. The discourses I read on Velandia's performative gesture, I suggest, do not come across for local audiences and the world music industry.

I propose the idea of the racial assemblage as a way to think about how musicking bodies with different - yet still hierarchical - racial formations interact and cohere as an array of bodies: as an assemblage of (racialized) bodies. Conceiving Carmelo Torres y Los Toscos as a racial assemblage stresses the relational quality of the collaboration and shows how discourses emerging from it are transformed in relation to changes across geopolitical scales. Furthermore, the way in which such discourses are circulated across geographical scales acts to link meaning with cultural and financial value. It is precisely the fluctuating nature of transcultural collaborations such as this one that the idea of the racial assemblage engages.

39 Appelbaum, Mapping the Country of Regions. 
Thinking at the intersection of sound, race, and place is key because the geopolitical has been fundamental in the construction of racializing assemblages from the colonial era to the contemporary moment. ${ }^{40}$

\section{National identity and the neoliberal turn: globalized localisms}

In the 1990s, president César Gaviria's 'economic openness' policy culminated the process of integrating neoliberalism in Colombia, a turn in economic restructuring throughout Latin America. In the music industry, this had the impact of dramatically downsizing what once was a flourishing local recording industry. As a result, sounds emanating from the global north dominated a good chunk of the programming and influenced the way local musics were produced. Major transnational corporations set local subsidiaries and/or purchased many local media industries. Going from a predominantly rural, poetic, and regional genre, vallenato exploded in the 1980s and into the 1990s, adapting production values and recording techniques from abroad and making itself more accessible to the diverse Colombian listener.

In the midst of these developments, groups of young, urban musicians started travelling to the Colombian peripheries in search of an alternative. Many of these had been academically trained in local schools that offered the standard Eurocentric and, to a lesser degree, jazz curriculum. A handful of them even earned graduate music degrees abroad. Fed-up with the Euro-American imports, and deeming vallenato as overtly commercial and cheesy, these urban subjects travelled to rural areas to experience local musics firsthand. Much like Stuart Hall argues, 'The trend towards "global homogenization", then, is matched by a powerful revival of "ethnicity", sometimes of the more hybrid or symbolic varieties, but also frequently of the exclusive or "essentialist" varieties. ${ }^{41}$ For many Colombian musicians living in the cities, this 'revival of ethnicity' came in the form of reclaiming what they thought (or imagined) was theirs.

This process is sardonically narrated and complicated in 'La antropología' by Edson Velandia, who - speaking as a hypothetical rural musician - sings about an unidentified gentleman from the capital who arrives to his peripheral hometown: 'A la sabana un caballero fue/Con un acento de la capital' ('A gentleman arrived to the province/He had an accent from the capital'). The unnamed character stands out not just for his accent, but also for the way he is dressed: 'Usaba gafas oscuras de Ray-Ban/Y unas abarcas que no le quedaban' ('He wore Ray-Ban shades/And sandals that did not fit'). The man's stylish shades index a cosmopolitan subjectivity that is contrasted with the indigenous footwear that does not fit. Velandia's lyrics speaks of the positionality of the urban subject aiming to have one foot

40 In the Colombian context, the music, race, and place relation has been partially explored by Wade (Music, Race \& Nation), and - adding a semiotic and affective lens - Oscar Hernández Salgar in 'Los mitos de la música nacional: poder y emoción en las músicas populares colombianas, 1930-1960 (Bogotá: Editorial Pontificia Universidad Javeriana, 2016).

41 Stuart Hall, 'The Question of Cultural Identity', in Modernity and Its Futures, ed. Stuart Hall, David Held, and Tony McGrew (Cambridge: Polity in Association with the Open University, 1992), 313. 
(or sandal) in his modern, metropolitan, and globally connected reality, and another in a timeless indigenous identity.

The drive to achieve aural authenticity is at the centre of the man's enterprise; an authenticity that he thinks he is entitled to because he happened to be born in an arbitrary geopolitical space that makes a nation and that he needs in order to circulate the 'people's cumbia' transnationally, thus becoming a legitimate exponent of this folk. The fragility of the nation concept, the primary rubric under which this music is being mobilized in the transnational market, is underlined by Velandia, when the gentleman in the song is confronted by the local musician and points out that his aspiring pupil cannot really learn how to play the 'people's cumbia': ' $Y$ yo le dije usted puede engañar/Al que no entiende de la melodía' ('And I told him you can deceive/Those who don't know about melody). This is emphasized by telling him that if he really wants to find his roots, his identity, he has to go back to his city: 'Pero si usted lo que quiere es raiz/Tiene que irse pa' su capital' ('But if what you want is roots/You have to go back to your capital').

This (dis)encounter is not only narrated through the lyrics. Rather, the negotiation is also taking place musically. In 'La antropología', Torres's accordion is a key feature, playing the intro, an instrumental soloistic bridge, and an outro. Andrés Landero's style is well represented by his pupil; there is a heavy yet syncopated rhythmic feel and a punchy attack on each note followed by a rich and potent sustained sound, something that Landero pioneered when he adapted not just the melodies, but also the playing style and even the timbre of the indigenous flute-like gaita to the European instrument. The upper-register of Carmelo Torres's diatonic Corona III button accordion is pungent and concise, going from heavily articulated in the beginning of each phrase to longer and robust notes towards the middle and end. These are complemented by his left hand, which plays a steady yet syncopated vamp. The melodies, though clearly on F minor, are built around its minor seventh chord, sometimes hinting towards its minor dominant chord.

Los Toscos provides a solid base. ${ }^{42}$ While the bass guitar and the guacharaca (scraper) are customary in accordion cumbia, both of them bring a back-beat-infused heaviness, creating a less syncopated and more downbeat-driven sense of groove. The bass creates a denser texture by using a fuzz pedal during the busier parts of the song, and by sliding in between the fifth and the tonic during some of the sections. The drums add to this rhythmic and textural density by constantly crashing on the downbeat. Interestingly, the indigenous alegre hand drum, which on the other tracks of the album supports and exalts Torres's regional style, is hardly present in 'La antropología'. The guitar goes from arpeggiated background accompaniments, to noisy, short soloist comments that develop into a dense and distorted wall of sound. Overall, Los Toscos seem to stay closer to Torres's style, signalling a process of transculturation carefully calculated by them, aiming to bring their globalized musicalities to the table without overrunning Torres, who, in the end, is the core of the whole project.

42 The studio band is: Pedro Ojeda (drum kit/timbales), Mario Galeano (scraper), Juan David Castaño (percussion), Enrique Mendoza (electric guitar), and Santiago Botero (bass). Most of them have undergraduate and graduate degrees in music, and all of them teach at local music schools at the university level. 
A desire for the 'national Other' is at the centre of both the collaboration and the song. Velandia narrates this when the rural subject (i.e., the Other) tells us how the man from the capital came to learn the tradition 'from the root': 'A mi me dijo el caballero aquel/Que pa' pegar había que ser raizal' ('The gentleman told me/That in order to make it you needed to be raizal'). The word raizal is key here. Broadly defining black or Amerindian communities with recognized and - most importantly - state-sanctioned ties and right to certain territories, the raizal concept has been recently mobilized, primarily by the state and media, in an effort to annex these marginalized communities and the systematic inequality and genocide they have endured into national discourse. Such efforts represent a timely addition to the nation project underway since the 1991 constitution declared Colombia a 'pluriethnic' and 'multiracial' country. $^{43}$

On the local and national scales, Velandia underscores the contradictions inherent to this aural and racial (dis)encounter. Switching shortly from the rural subject's point of view into his own, in the chorus Velandia exposes the desire for the Other and its aural authenticity - a libidinal economy or economy of desire - but also the very flawed nature of this enterprise, since 'Una cosa es el indio/Y otra cosa es la antropología', a chorus that - perhaps intentionally - uses the loaded word indio that to this day still functions in Colombia as a racial slur directed towards Amerindian populations, and often as an insult amongst white mestizos to refer not necessarily to their racial background, but to someone rude, uneducated, and ignorant. Used within the colloquial expression translatable to 'theory is one thing, and practice is another thing', the chorus encapsulates, on the one hand, the contradictions inherent in desiring the racial Other in a racially unequal country and, on the other hand, the impossibility of the urban gentleman in grasping these traditions, since his roots are - in Velandia's words - 'in the capital'. This is a narrative that touches a sensitive root in a local music scene in which a notion of authenticity based on place - that is, equating national origin with a sort of 'folk legitimacy' - has become a source of financial and cultural capital for Colombian white-mestizo musicians, particularly in the Euro-American market.

There is an insightful self-reflexivity to the collaboration and to the song itself. Both its text and music constitute a sort of meta-criticism, as the band themselves (Los Toscos) can potentially be the unnamed urban dilettante. However, this relation can be complicated. Landero's accordion cumbia fell outside of the national (or nationalistic) canon. Thus, Los Toscos are not playing into hegemonic notions of nation and aural national identity. Rather, by engaging with these apocryphal sounds, they are going beyond the mediated notion of what Colombian accordion music is supposed to be, potentially complicating what national music and, more fundamentally, what the Colombian subject is.

43 The importance of the Colombian 1991 constitution cannot be understated. Besides investing Afro and Indigenous communities with rights and political representation, it also marked a de facto transition from a mestizo-based (mixed-race) to a 'multiracial/multicultural'-based national discourse. For an overview of the evolution of racial formations in Colombia, see Restrepo et al., 'Nation and Difference in the Genetic Imagination of Colombia'. 


\section{From the national to the transnational: '¡Colombian Roots meets Garage Fuzz!'}

While for the Colombian listener the act of rendering Carmelo Torres y Los Toscos is mediated by the many discourses that make the nation, foreign consumers lack such a context. In this section, I trace how the racial assemblage is circulated in the transnational market. Following Ochoa Gautier, ${ }^{44}$ I use the word recontextualization to discuss the prominent role the music industry plays in creating meaning around local musics. According to her: 'the construction of knowledge about traditional music shares with the recording industry the act of musical entextualization and recontextualization as fundamental practices'. ${ }^{45} \mathrm{I}$ show how, to make this racial assemblage intelligible, the transnational industry subsumes and further essentializes it under the category of nation. Shortly after the album Carmelo Torres y Los Toscos was released in CD format in Bogotá, some of its tracks were re-issued by Brooklyn-based label Name You Can Trust (NYCT) and France-based label Galletas Calientes (Hot Cookies), both in 2016. Each of these vinyl 45 RPM 7" discs contains one track on each side. Interestingly, 'La antropología' was not included on either. This begs the question: why, from a total of four tracks that were selected for international pressing, was 'La antropología' not included?

In their 'about' page, NYCT presents itself as an independent label manufacturing 'a mix of vintage \& modern sounds typical of the New York experience' that intimately connects to the city's immigrant population. The label's roster is 'a perfect glimpse into the global yet local New York City underground. ${ }^{46}$ Importantly, the label's catalogue, currently composed of more than sixty vinyl releases, focuses on current trends of pan-Latin American dance musics such as cumbia and, to a lesser degree, salsa. Lately, NYCT has been strengthening its ties to the Colombian cumbia scene, publishing local underground referents Meridian Brothers, Romperayo, and Frente Cumbiero.

While NYCT has been expanding its roster, it is still dominated by New York City-based projects. The label was launched in 2007 with a $12^{\prime \prime}$ EP by their 'flagship operation' - as NYCT calls it - Greenwood Rhythm Coalition. Likely alluding to the Greenwood Heights neighbourhood in Brooklyn, New York, the band's 'unique hybrid of Latin \& Caribbean rhythms, B-Boy breaks, live instrumentation and studio wizardry have earned their vinyl releases critical acclaim amongst the DJs and mass appeal on the dance floor ${ }^{37}$ The underground globalized sonority of the band prefaced NYCT's international expansion. Contemporary sounds - arguably 'uniquely hybrid' in the label's ears - emanating from Latin America, the United States, and Europe have shaped NYTC's reputation as a leader in the emerging independent circuit of a trend I would call 'pan-Latin American musics meets globalized grooviness'. Carmelo Torres y Los Toscos forms part of a recent interest NYCT has taken in showcasing

44 Ana María Ochoa Gautier, 'Sonic Transculturation, Epistemologies of Purification and the Aural Public Sphere in Latin America'. Social Identities 12/6 (2006).

45 Ochoa Gautier, 'Sonic Transculturation', 805.

46 Names You Can Trust. 'About Names You Can Trust'. Names You Can Trust. nda. www.nyctrust.com/about-us/ (accessed 5 December 2018).

47 Names You Can Trust, 'About Names You Can Trust'. 
relevant yet little known Colombian artists. ${ }^{48}$ In the particular case of Carmelo Torres y Los Toscos, no money exchange has taken place. Rather, the label covers the costs of mixing and pressing, and gives a quota of the copies to the musicians, a fairly common practice.

Galletas Calientes was originally created by two DJs who were active in France's 'underground free rave party movement' during the 1990s. ${ }^{49}$ According to them, the 'amigo's project of a two-man-band creating a fusion of Latin music and French songs' eventually landed in 'South America'. Once in Colombia, they 'embarked on an intense and passionate exploration of modern and past Colombian folklore. ${ }^{50}$ Having a smaller roster than that of NYCT, with only close to twenty releases on vinyl, $\mathrm{CD}$, and digital formats, Galletas Calientes focuses mostly on 'modern and past' Colombian music, with an emphasis on current Afro-Colombian sounds. For them, "'the new Colombian scene" cleverly and skillfully adapted all types of other genres to the richness of its folklore' thus 'embody[ing] the new concept the label was embracing. ${ }^{51}$

NYCT exalts New York City as the centre and quintessential example of human migration and the music cosmopolitanism that comes with it; New York City is thus reified as the fundamental place from which these local musics are funnelled into the global north consumer. By rendering Carmelo Torres y Los Toscos as ‘Colombian Roots meets Garage Fuzz! on a stamp-like seal on the front and back cover, NYCT recontextualizes it, subsuming this complex racial and musical assemblage under an obscure category that invokes the nation. The '¡Colombian Roots meets Garage Fuzz!' aphorism underlines the liminality of the record. If, on the one hand, 'roots' invokes a racialized exoticized sonority, the 'garage fuzz' alludes to a racially unmarked aurality. The lingua franca 'garage fuzz', and the Anglo aesthetic it presupposes, bridges the epistemological gap between the 'rootsy' (the raizal in Velandia's words) and 'the modern'. Ochoa Gautier argues that such recontextualization of sounds involves 'localizing global sounds as well as globalizing local ones' ${ }^{52}$ something that is at the core of NYCT's politics of circulation. The 'authentic yet hybrid', 'folksy yet modern', 'indigenous yet cosmopolitan' discourse becomes crucial in the mediating process. Ultimately, the record constitutes, in the words of NYCT, 'the quintessential bridge between the old and new generations of Colombian musicians' ${ }^{53}$

48 Names You Can Trust, 'El Chacho, by Carmelo Torres y Los Toscos', Names You Can Trust. https://nyctrust. bandcamp.com/album/el-chacho. Aside from Carmelo Torres y Los Toscos, this trend includes the 2018 release Abelardo Carbonó y su Grupo (NYCT-7038). Mostly active during the 1980s, Carbonó's guitar style was influenced by local genres and the African sounds of afrobeat, soukus, and highlife. NYCT vinyl makes part of a broader wave (emanating mostly from Europe) of 'rediscovering' Carbonó's idiosyncratic sound. Interestingly, for NYCT's album, Carbonó is accompanied by renowned British cumbia DJ Quantic (Will Holland) and Colombian producer/musician Mario Galeano (who also makes part of Carmelo Torres y Los Toscos). Thus, the theorization I am proposing here could be expanded to Carbonó's case.

49 Galletas Calientes, 'About Galletas Calientes!', Galletas Calientes, www.galletascalientes.com/about/.

50 Galletas Calientes, 'About Galletas Calientes!', emphasis added.

51 Galletas Calientes, 'About Galletas Calientes!'

52 Ochoa Gautier, 'Sonic Transculturation', 805.

53 Names You Can Trust, 'El Chacho, by Carmelo Torres y Los Toscos'. 
This narrative is echoed by Galletas Calientes. Connecting Torres to the legacy of Landero and describing Los Toscos as 'an avant-garde, experimental jazz band from Bogotá', ${ }^{54}$ they also stress the aurally and racially mediated nature of the project, even reproducing NYCT’s ‘CColombian Roots meets Garage Fuzz!’ moniker. Analyzing these acts of recontextualization exposes the sensitive balance of this equation. Thus, returning to the question of why 'La antroplogía' was not included in either of the foreign reissues, we can see how it is not so much that Velandia's lyrics are considered a scalding critique to the way this music is being circulated and, by extension, to these foreign labels' modus operandi. Rather, 'La antropología', featuring a third white mestizo party singing an original song outside the traditional songbook, makes this musical and racial assemblage too complex, making it - once again - potentially unintelligible and inaudible.

This signals an economy of desire based not so much on authenticity, but on never-ending hybridity. That is, contrary to erasing the mediation, these acts of recontextualization underline the hybrid quality of this racial assemblage. As Joshua Tucker - echoing Timothy Taylor - argues, 'the theoretical discovery of permanent hybridity and the glorification of an experimental spirit tend to enforce new modes of authenticity, reworking hierarchies of social and aesthetic distinction rather than assuaging such inequalities'. ${ }^{55}$ Thinking from the current state of Peruvian cumbia, Tucker insightfully critiques scholarly discourses that exalt hybridity as an alternative to essentialized discourses of cultural purity. ${ }^{56}$

Making Carmelo Torres legible (and audible) to the national and transnational consumer seems to be an important part of what this project is doing. Shortly after the CD was released in Bogotá, for example, Carmelo was profiled in mayor media outlets such as Arcadia (one of the major national cultural magazines) and in Noisey (VICE's music journalism online platform). While Carmelo Torres has been an active performer for decades, mainstream media started covering him after 2016. This double-mediation that Los Toscos as well as NYCT and Galletas Calientes do for Carmelo Torres has put him on the radar of the international circuit. Over the past few years, he has been touring widely over Latin America, Europe, and Africa, mostly with his own band. More recently, the crew of BBC Radio's podcast The Sound Odyssey travelled to Colombia to meet with Carmelo, interview him, and document his collaboration with British musician/actor Johnny Flynn, a (dis)encounter that I turn to next.

\section{Sounding the erasure: the BBC meets Carmelo}

The Sound Odyssey is a series of BBC documentary podcasts in which British musicians travel to different parts of the world to embark in transcultural collaborations with local artists.

54 Galletas Calientes, 'Carmelo Torres y Los Toscos', Galletas Calientes, www.galletascalientes.com/carmelo-torres-y-lostoscos/.

55 Joshua Tucker, 'Peruvian Cumbia at the Theoretical Limits of Techno-Utopian Hybridity', in Experimentalisms in Practice: Music Perspectives from Latin America, ed. Ana R. Alonso-Minutti, Eduardo Herrera, and Alejandro L. Madrid (New York: Oxford University Press, 2018), 89.

56 Tucker focuses on the boom in Peruvian cumbia over the last decade, particularly with the release of the compilation The Roots of Chicha (2007), in order to investigate the theoretical limits of academic discourses of hybridity. Joshua Tucker, 'Peruvian Cumbia at the Theoretical Limits of Techno-Utopian Hybridity'. 
Hosted by Gemma Cairney, the series aims to showcase these British artists in a new light... exposing their artistic process as they create something new in different and unfamiliar surroundings with an artist they have never met before'. ${ }^{57}$ For Carmelo's episode, they invited musician/actor Johnny Flynn, described by the BBC as a 'folk song collector' particularly interested in 'the migration of musical instruments especially in South American and Amazonian culture'. ${ }^{58}$ In his transcultural voyage, Flynn is interested in charting cumbia 'ethnographically, or anthropologically, through the instruments and the architecture of what people are capable of making through the technology that they have'. The specific 'technology' he refers to is the European accordion, highlighting the fact that he is familiar with the three-row button diatonic type used in accordion cumbia and that he has used in a lot of traditional British folk music'. ${ }^{59}$

On the 26-minute podcast, eighteen of them are spent talking with Colombian interlocutors about Carmelo Torres, accordion cumbia, Colombia, and Bogotá. These interlocutors are knowledgeable members of the emerging cumbia scene, including producers, managers, and performers. Mario Galeano, one of the leading figures of this scene and the guacharaquero (scraper player) on Carmelo Torres y Los Toscos, comments that Carmelo's is a musical tradition that is 'in decline'. He describes the collaboration between them (Los Toscos) and Torres as thus 'we, a whole bunch of really noisy [guys] playing in the background'. It is likely the BBC 'discovered' Carmelo through Los Toscos, as indicated by the fact that when Carmelo's music is played in the background, all of the tracks come from their collaborative album. Finally, during minute eighteen, Carmelo is interviewed. Questioned about the history of the accordion in Colombia and his thoughts on the collaboration with Flynn, Torres replies that he is happy with it as he is always up to 'innovate'.

A fascinating moment of anthropological gaze is captured when Cairney (the hostess) narrates Carmelo and his band's first meeting with Flynn as it unfolds. First, Carmelo is introduced to Flynn's idea of adapting the lyrics of an old British folk ballad to a cumbia beat. Flynn explains that these words were collected in an old book without melody. As Cairney describes the scene, Carmelo's accordion and the scraper interlace with Flynn's fiddle and a guitar in a clumsy jam. After a short chat between them, Flynn presents the books from which he extracted the lyrics to Carmelo and asks for his approval while explaining that he intended to 'make that into a cumbia song'. Then, we hear a Colombian musician (perhaps from Carmelo's band) teaching Torres the first chords of Flynn's arrangement. Translating from strummed guitar into the voice, this 'musical decoder' turns the chords into sung triads in order to make them more familiar to Carmelo's ear. Over the guitar and the scraper, this 'decoder' sings what he calls 'first position' to Carmelo - likely something similar to the Western concept of tonic - a D chord that constitutes the tonal centre of the arrangement. Carmelo quickly catches on and plays it in his style.

57 BBC, 'Johnny Flynn Travels to Colombia', The Sound Odyssey, Series 1, 19 September 2018. www.bbc.co.uk/ programmes/b0bk1fbr.

58 BBC, 'Johnny Flynn Travels to Colombia'.

59 BBC, 'Johnny Flynn Travels to Colombia'. 
Without stopping, and keeping the harmonic rhythm, the decoder sings the next chord: a $\mathrm{C} \sharp$ diminished triad. Immediately, Torres hesitates, struggling to find the pitches. Instead, he plays an E diminished triad. Arguably due to the fact this chromatic movement is odd for Carmelo's ear and his accordion technique, instead of moving to the seventh chord (C\# dim.) he moves to the second degree (E dim.). As this happens, Cairney continues to narrate the scene: 'at the moment, there's a lot of discussion trying to work out how we can get Carmelo to connect with this British folk sound and vice versa. So, there's a discussion about simplifying certain parts of the song to make it more cumbia. ${ }^{60}$

The overall scene and Cairney's narration expose the complexities of the (dis)encounter. Signalling an Eurocentric ear, the host sets up a simplicity-complexity scale based on Western tonal harmony. It follows that, in order to make Flynn's arrangement 'more cumbia', it has to be simplified; a simplification that - while is not explicitly expressed by any of the parts - has to do with modifying (or 'simplifying') the chromatic harmonic movement in order to bridge the epistemological gap. Interestingly, in the final recording the chromatic harmonic movement was not excised. Rather, we hear Carmelo constantly stepping out of the groove when the $\mathrm{C} \sharp$ dim. chord kicks in: a micro-erasure in Carmelo's own 'sounding'. This collaboration process contrasts with Los Toscos's. The latter's familiarity with Carmelo's music genealogy - not just with the music's history but its stylistic features makes the mediation process smoother. Flynn's collaboration, on the other hand, is quite rocky, and the end product, while still retaining Torres' idiosyncratic sonority, has a more Frankenstein-ish quality to it, making the sutures of interculturalism more audible.

While both Flynn and Los Toscos desire Torres's musicality, the process goes differently for each of them. Scaling these collaborations, we can identify important nuances between the national (Los Toscos) and the transnational (Flynn) subject, and see how indeed the racial liminal subject does make a difference, not only in the way the musical collaboration unfolds, but also on how these racial assemblages are circulated. For Carmelo Torres and Los Toscos, the nation category makes the assemblage more stable, more hearable, and thus more marketable. In contrast, the Carmelo-Flynn assemblage lacks aural clarity and geopolitical stability. To be clear, the intent behind Flynn and the BBC crew seems far from pernicious. Flynn elaborates his thoughts on tradition using the famous Mahler quote 'tradition is tending the flame, not worshiping the ashes'. While Mahler's concept of 'tradition' is arguably a far cry from Flynn's, in this context it seems to echo Carmelo's impetus for 'innovation'. While commendable in spirit, this approach to transculturalism presupposes a meeting between equals. On this point, I echo Joshua Tucker's admonition:

For scholars interested in the health of the relationship between sound and society, or experimental music and social justice, hybridity and its cognates cannot be casually invoked as palliatives for older, colonialist discursive frames that have been found wanting. The empire does indeed strike back, and as indigenous activists and scholar allies have long known, hybridity discourse is one of its preferred tools, for its

60 BBC, 'Johnny Flynn Travels to Colombia', emphasis added. 
boundary-challenging rhetoric is useful in denying local cultural specificities and hence the very existence of the ethnic basis on which populations have been and continue to be oppressed. ${ }^{61}$

\section{Anthropologizing the Self and the Other: aural self-cannibalization}

A desire for the Other runs throughout both the song 'La antropología' and Carmelo's (dis) encounter with the cosmopolitan music scene. The title of the track alludes to a fundamental feature of both the world music industry and ethnomusicology: making the Other the object of anthropological gaze. As Roshanak Kheshti argues, this economy of desire is at the core of the world music concept. For Kheshti, ethnomusicology and world music constitute two sides of what she calls the 'world music culture industry'. Following her, I conceive this industry as one that 'is characterized by brokering - whether in exchange for actual or symbolic capital in racialized gender'. ${ }^{62}$ The figure of the racial liminal subject is fundamental, rendering racialized sounds audible. ${ }^{63}$ Velandia's song speaks eloquently of the inextricable relation ethnomusicology has with - in the words of Khehsti - its 'commercial doppelganger' world music. ${ }^{64}$ However, scaling this racial assemblage shows us that over the last century North-South power structures have mutated. The act of mediating is no longer the privilege of the Anglo-centric world music industry. There is a shared agency to be accounted for.

To be sure, this agency is distributed between the labels who circulate the music and the artists who mediate it. For the latter, such agency tends to fall on the racial liminal subject. The current state of cumbia's circulation certainly illustrates this. As the aforementioned studies by Madrid, Fernández L'Hoeste, Baker, and Tucker show, ${ }^{65}$ the current transnational circulation of these musics are headed by middle- and upper-class musicians from the Latin American metropoles and/or settled in the global north. Whether strategically or not, mobilizing regional racialized sounds has become a way to position these white-mestizo musicians in the global circuit.

61 Tucker, 'Peruvian Cumbia at the Theoretical Limits of Techno-Utopian Hybridity', 105-6.

62 Roshanak Kheshti, Modernity's Ear: Listening to Race and Gender in World Music (New York: New York University, 2015), 6.

63 Tracing the origins of ethnomusicology and the world music industry, Roshanak Kheshti situates the work of American female musicologists such as Frances Densmore as their direct predecessor. Reflecting on the iconic picture showing Densmore, a phonograph, and 'Blackfoot Mountain Chief, Kheshti argues that the Indian Other was rendered intelligible not just via reproduction technologies, but also through the white female musicologists making the recordings. These early twentieth-century scholars, Kheshti argues, stood in a 'liminal racial space' in an era of social Darwinism, being below the normative white male but above her racialized other. Female musicologists like Densmore, along with reproduction technologies, mediated the less-than-human's aurality and made it hearable to the Western subject. This set the bases for the field of ethnomusicology and the world music industry. For Kheshti, documenting these sounds provided the Other with 'history', thus making them into an object of knowledge for the Eurocentric social sciences. By doing so, this Other was further commodified and fetishized by the media industry. Kheshti, Modernity's Ear.

64 Kheshti, Modernity's Ear.

65 Madrid, Nor-tec rifa!i; Fernández L'Hoeste, 'The Impact of Tropipop on Colombia's Music Scene’; Baker, “'Digital indigestion"; Tucker, 'From the World of the Poor to the Beaches of Eisha' and 'Peruvian Cumbia at the Theoretical Limits of Techno-Utopian Hybridity. 
In the Colombian music scene this is a disputed and volatile terrain. From local musicians who want to capitalize on the cumbia boom, to judicious researchers of this music and everything in between, Velandia's message in 'La antropología' echoes a critical point of view that touches a sensitive fibre in a compact music community. As stated above, Carmelo Torres $y$ Los Toscos feat. Velandia's song constitutes an act of self-reflexivity and meta-criticism that, far from being a foregone conclusion, signals an ongoing discussion over how identity is negotiated and continuously reconfigured through the music-nation dyad. While for the Colombian listener the message of 'La antropología' could be buried under its whimsical, seemingly playful tone and floor-filler quality, Velandia has been openly critical about the local cumbia scene.

In conversation with Colombian musician Yesit Ipuján, Velandia asks, 'Don't you find this cumbia boom annoying?' ('¿no te fastidia un poco ese boom de la cumbia?'). ${ }^{6}$ He then elaborates, arguing that he finds this 'trend' a bit 'snob and opportunistic', not because it is a novelty due to the fact that - for him - cumbia has always been around. For Velandia, the difference lies in the fact that now the music has turned into a fetish, an exotic commodity. In his words, he sees the recent developments in cumbia's transnational circulation as 'looking at ourselves through an exoticized gaze' ('es como mirarnos exóticamente a nosotros'). Riffing off his interlocutor, Velandia uses the world 'anthropological' (drawing a subconscious connection to his song) to express this act of auto-inflicted exoticized gaze. That is, the act of making oneself the object of anthropological inquiry.

For Velandia, this act of aural self-cannibalization implies annexing oneself to the world music industry ('Aceptar por ejemplo términos como que nosotros somos música del mundo'). This, he states, is 'one of the most pathetic and colonialized things there can be: accepting that you belong to that [industry]' ('Ésa es una de las cosas más patéticas y más colonialistas que puede haber: aceptar que uno pertenece a eso'). ${ }^{67}$ We can see how deep Velandia's reservations run. The fact that he expresses them through his sardonic poetics in a collaboration centred around cumbia makes his song with Carmelo Torres and Los Toscos a potential Trojan horse. Interestingly, both Velandia and Ipuján are not based in the major Colombian cities such as Bogotá, Medellín, or Cartagena, where this boom has been taking place. ${ }^{68}$ The geopolitical is relevant here, as both of them are looking to this cosmopolitan scene from the outside, perhaps with a critical insight brought by living in the 'periphery'.

In the midst of this overlapping discourses, it is important to ask how the listeners are interacting with them. This is a complicated question. In Colombia, the small niche market consuming these underground musics precludes any massive impact. Here, thinking about place becomes useful, as situating this music in the context of where it is being consumed can shed

66 Fabián Paéz López, 'Edson Velandia y Acid Yesit: Una Charla Sobre Cumbia, Arte y Oportunismo', Shock, 12 April 2017, www.shock.co/musica/edson-velandia-y-acid-yesit-una-charla-sobre-cumbia-arte-y-oportunismo-ie35.

67 Paéz López, 'Edson Velandia y Acid Yesit'.

68 Though both Velandia and Ipuján travel constantly to these cities (particularly Bogotá) to play gigs, Velandia is based in the town of Piedecuesta, in the northeastern Santander state. Ipuján and his band Acid Yesit, are based in Pasto, in the southern Andes, a few hours' drive to the Ecuadorian border. 
light on issues of reception. Founded in $2008,{ }^{\star}$ matik-matik ${ }^{\star}$ is a bar/venue that has become one of the most important spaces for underground musics in Bogotá. Most of the Colombian projects published by NYCT have either developed or were born there, including Carmelo Torres y Los Toscos. French-born Benjamin Calais, the producer behind the project, runs ${ }^{*}$ matik-matik ${ }^{*}$. The venue has become one of the most important nodes of the Bogotano music scene, nourishing projects that go from improvisation, contemporary music, multimedia, 'tropical noise', and much more. The place has been fundamental in supporting the underground music scene and providing musicians who work at the fringes of the aesthetically normative with a space to work and create community, including myself.

The project Los Toscos is a product of the scene nurtured by this venue. Located in a middle-class area of Bogotá, ${ }^{*}$ matik-matik ${ }^{*}$ and its bold programming attracts mostly university students, artists, and young professional, predominantly white mestizos. The venue expanded into a record label ( ${ }^{*}$ matik-matik ${ }^{\star}$ discos), which originally released the album Carmelo Torres $y$ Los Toscos. I opened this article describing the release party that took place there. In a videoclip available on YouTube, ${ }^{69}$ we can see the full band (Carmelo, Los Toscos, and Edson Velandia) in action. The event was indeed a party. Standing up and dancing through the song, the audience joins Velandia in the catchy chorus 'Porque una cosa es el indio y otra cosa es la antropología' ('The indian is one thing, anthropology is another'). The chorus's vernacular and witty nature makes it instantly memorable. Velandia approaches Carmelo, sharing the microphone with him momentarily to sing the loaded words, thus epitomizing the racial assemblage I have discussed.

In Los Toscos's YouTube channel, at the time I am writing this, ${ }^{70}$ the studio track of 'La antropología' has gathered over 176,000 views, a fair amount for this type of music. Of the sixty-plus comments the song has to this day - the vast majority from Colombians based on the vernacular - most of them are shout-outs and congratulations. A couple of them do address the songs' content, reading it as a humorous critique to anthropologists (and other social sciences scholars) and their relation to indigenous communities. Through my experience in this music scene, it is hard to assure that the issues I am reading through Velandia's words have permeated the community. Rather, I see younger generations of musicians in the cities turning to local musics such as cumbia and reclaiming their 'cultural heritage'. It would be irresponsible to essentialize a widely diverse music scene that includes people from very different backgrounds, artistic motivations, and aesthetic practices. As this investigation shows, far beyond a homogenous community, the current state of cumbia in Colombia constitutes a disputed and heterogenous terrain. Nevertheless, nationalist discourses continue to prevail, making them a regulating concept for many local artists.

The ways in which each of the parts of the assemblage negotiate their relation to cumbia sheds light on the complex discourses put in motion by this music's circulation. Furthermore, scaling this circulation shows us how meaning is indeed contingent to place, what Weheliye, following Deleuze and Guattari, calls the 'spasmodic quality of

69 www.youtube.com/watch?v=jC42qrp25o8.

70 October 2019. 
assemblages'. ${ }^{71}$ Apart from, and mostly unconcerned with, ideas of musical 'authenticity' or 'hybridity' - so pervasive nowadays and that more often than not stem from an Eurocentric gaze - Carmelo Torres is invested in un-silencing and advancing Andrés Landeros's legacy. Collaborating with national and foreign artists has proved to be an effective strategy in doing so. Los Toscos's liminality resounds both locally and abroad. It is through them that Torres is rendered intelligible to the middle-class, white mestizo, young listener. As I have shown, such liminality is paralleled by the complicated ways in which the band fits in the country of regions' that is Colombia, going simultaneously with and against the grain of normative local discourses of music, race, and nation. Finally, Velandia, looking to the historical relation of alterity between 'the coast' and 'the interior' from the outside and critically approaching the current cumbia boom, insightfully problematizes this (dis)encounter. The witty tone of the critique seem to mask its causticness for local audiences. Once this assemblage is mediated by foreign record labels and catered to the global north consumer, all these issues seem diluted and are subsumed into the independent world music industry.

\section{Closing remarks: cannibalistic auralities, or who is the cannibal?}

The double-mediation that Los Toscos and NYCT and Galletas Calientes do for Carmelo Torres put him on the map of the underground international circuit. This is a mediation not unlike the one described by Velandia, when the local cumbia musician tells us how the gentleman from the capital begs him to teach him how to acquire his aural authenticity: 'Cómo hago yo pa' que me suene propio/Me preguntaba que yo le dijera' ('How do I do to sound legit/He kept asking me'). This music, the gentleman tells the local musician, is very desired, not locally but abroad: 'Que aquí en Colombia no es la sensación/Pero en Europa sí es apetecida' ('That in Colombia is not that popular [the music]/But in Europe is very desired'). Nevertheless, such 'pre-modern' aurality needs to be mediated by the local cosmopolitan subject in order to commodify it: 'Esa cultura de tribu caníbal/Que ellos no entienden cuando es natural' ('That culture of cannibal tribe/They don't understand in its natural state').

Quite explicitly, Velandia underlines how these racialized, potentially sub-human sounds need to be funnelled through the racial liminal subject if they are to be circulated. This is an asseveration not far from the truth, as several of the bands working with cumbia that have emerged in Colombian cities over the last ten or more years continue to tour profusely in the global north, particularly in the European summer festival circuit. As in the song, these bands tend to offer the mediated 'local yet cosmopolitan' sound.

As Trouillot argued, microlevel analyses like this one provide us with the ethnographic clarity and theoretical insights to critically approach emerging racial formations and modes of consumption. $^{72}$ The desire for this music continues to grow worldwide. However, unlike many of its regional incarnations that carry the burden of its racialized and classed past, cumbia's current circulation plays a balancing act between commodifying and mediating difference, thus recasting the libidinal economy of the - now independent - world music

71 Weheliye, Habeas Viscus.

72 Trouillot, Peasants and Capital. 
industry anew. While Velandia's humorous and sharp account tells us about a 'cannibal culture' that is unintelligible to the Eurocentric gaze in its 'natural state', the cannibalistic seems to remain an adequate rubric to think how local musics flow in the neoliberal market.

\section{Bibliography}

Agard-Jones, Vanessa. 'Bodies in the System'. Small Axe: A Journal of Criticism 42 (2013), 182-92.

Althusser, Louis. 'Ideology and Ideological State Apparatuses: Notes towards an Investigation', in Lenin and Philosophy, and Other Essays, with introduction by Fredric Jameson, trans. Ben Brewst. New York: Monthly Review Press, 2001.

Appelbaum, Nancy P. Mapping the Country of Regions: The Chorographic Commission of Nineteenth-Century Colombia. Chapel Hill: University of North Carolina Press, 2016.

Arévalo Mateus, Jorge and Martín Vejarano. ‘¿Pa' dónde vas Marioneta? ¿Pa' dónde va la gaita?: La Cumbiamba Eneyé Returns to San Jacinto', in Cumbia!: Scenes of a Migrant Latin American Music Genre, ed. Héctor, Fernández L'Hoeste and Pablo, Sergio Vila. Durham, NC: Duke University Press, 2013. 49-86.

Baker, Geoffrey. "'Digital indigestion”: Cumbia, Class and a Post-Digital Ethos in Buenos Aires'. Popular Music 34/2 (2015), 175-96.

BBC. 'Johnny Flynn Travels to Colombia'. The Sound Odyssey, Series 1, 19 September 2018. www.bbc.co.uk/ programmes/b0bk1fbr (accessed 10 December 2018).

Blanco Arboleda, Darío. Los colombias y la cumbia en Monterrey: identidad, subalternidad y mundos de vida entre inmigrantes urbanos populares. San Nicolás de los Garza, NL, México: Facultad de Filosofía y Letras, Universidad Autónoma de Nuevo León, 2014.

Calle, Simón. 'Reinterpreting the Global, Rearticulating the Local: Nueva Música Colombiana, Networks, Circulation, and Affect'. PhD diss., Columbia University, 2012.

Deleuze, Gilles, Brian Massumi, and Félix Guattari. A Thousand Plateaus: Capitalism and Schizophrenia. Minneapolis: University of Minnesota Press, 2003.

Dorr, Kirstie A. On Site, In Sound: Performance Geographies in América Latina. Durham, NC: Duke University Press, 2018.

Fernández L'Hoeste, Hector. 'On Whitening and Other Disaffections: The Impact of Tropipop on Colombia's Music Scene', in Music and Youth Culture in Latin America: Identity Construction Processes from New York to Buenos Aires, ed. Pablo Vila. New York: Oxford University Press, 2014. 157-73.

Fernández L’Hoeste, Héctor, and Pablo Vila. Cumbia!: Scenes of a Migrant Latin American Music Genre. Durham, NC: Duke University Press, 2013.

Galeano, Mario. 'Guacharaca Calling'. Noisey, VICE. 2015. https://noisey.vice.com/es_co/article/rbzbba/ guacharaca-calling (accessed 5 December 2018).

Galletas Calientes. 'About Galletas Calientes!' Galletas Calientes. www.galletascalientes.com/about/ (accessed 5 December 2018).

—. 'Carmelo Torres y Los Toscos'. Galletas Calientes. www.galletascalientes.com/carmelo-torres-y-los-toscos/ (accessed 5 December 2018).

Guattari, Félix. Chaosmosis: An Ethico-Aesthetic Paradigm. Sydney: Power Publications, 1995.

- The Machinic Unconscious:Essays in Schizoanalysis. Cambridge, MA: Semiotext(e), 2011.

Hall, Stuart. 'The Question of Cultural Identity', in Modernity and Its Futures, ed. Stuart Hall, David Held and Tony McGrew. Cambridge: Polity in Association with the Open University, 1992. 272-325.

Hernández Salgar, Oscar. 'Colonialidad y postcolonialidad musical en Colombia'. Latin American Music Review 28/ 2 (2007), 242-70.

- Los mitos de la música nacional: poder y emoción en las músicas populares colombianas, 1930-1960. Bogotá: Editorial Pontificia Universidad Javeriana, 2016.

Kheshti, Roshanak. Modernity's Ear: Listening to Race and Gender in World Music. New York: New York University, 2015.

Madrid, Alejandro L. Nor-tec rifa!: Electronic Dance Music from Tijuana to the World. New York: Oxford University Press, 2008.

Maldonado-Torres, Nelson. 'Post-continental Philosophy: Its Definition, Contours, and Fundamental Source'. Worlds \& Knowledges Otherwise 1/2 (2006), 1-29.

Names You Can Trust. 'About Names You Can Trust'. Names You Can Trust. nda. www.nyctrust.com/about-us/ (accessed 5 December 2018).

. 'El Chacho, by Carmelo Torres y Los Toscos'. Names You Can Trust. ndb. https://nyctrust.bandcamp.com/ album/el-chacho (accessed 5 December 2018). 


\section{Rubio Restrepo 'Una cosa es el indio y otra cosa es la antropología'}

Ochoa, Juan Sebastián. 'La cumbia en Colombia: Invención de una tradición'. Revista Musical Chilena 70/226 (2016), 31-52.

Ochoa Escobar, Federico. 'Las investigaciones sobre la caña de millo o pito atravesao'. Cuadernos de Musica, Artes Visuales y Artes Escenicas 7/2 (2012), 159-78.

_. El libro de las gaitas largas. Bogotá: Editorial Pontificia Universidad Javeriana, 2013.

Ochoa Gautier, Ana María. 'García Márquez, Macondismo, and the Soundscapes of Vallenato'. Popular Music 24/2 (2005), 207-22.

- 'Sonic Transculturation, Epistemologies of Purification and the Aural Public Sphere in Latin America'. Social Identities 12/6 (2006), 803-25.

Olvera Gudiño, José Juan. Colombianos en Monterrey: origen de un gusto musical y su papel en la construcción de una identidad social. Monterrey, NL, Mexico: Consejo para la Cultura y las Artes de Nuevo León, 2005.

Páez López, Fabián. 'Edson Velandia y Acid Yesit: Una Charla Sobre Cumbia, Arte y Oportunismo'. Shock, 12 April 2017. www.shock.co/musica/edson-velandia-y-acid-yesit-una-charla-sobre-cumbia-arte-y-oportunismo-ie35 (accessed 7 December 2018).

Quijano, Anibal, and Michael Ennis. 'Coloniality of Power, Eurocentrism, and Latin America'. Nepantla: Views from South 1/3 (2000), 533-80.

Restrepo Eduardo, Ernesto Schwartz-Marín, and Roosbelinda Cárdenas. 'Nation and Difference in the Genetic Imagination of Colombia', in Mestizo Genomics: Race Mixture, Nation, and Science in Latin America, ed. Peter Wade, Carlos López-Beltrán, Eduardo Restrepo, and Ricardo Ventura Santos. Durham, NC: Duke University Press, 2014. 55-84.

Revista Arcadia. 'Carmelo Torres y el futuro de la cumbia'. 8 February 2018. www.revistaarcadia.com/impresa/ musica/articulo/entrevista-con-carmelo-torres-el-heredero-de-la-cumbia-sabanera-de-andres-landeros/68043 (accessed 10 December 2018).

Rubio Restrepo, Juan David. 'Cumbias y rebajadas: Aurality, Race, and Class in Monterrey's "colombia" Culture', in Scattered Musics, ed. Martha Chew Sánchez and David Henderson. Jackson, MI: University Press of Mississippi, forthcoming.

Sevilla Peñuela, Manuel Enrique, Juan Sebastián Ochoa Escobar, Carolina Santamaría Delgado, and Carlos Eduardo Cataño Arango. Travesías por la tierra del olvido: modernidad y colombianidad en la música de Carlos Vives y la Provincia. Bogotá, DC: Editorial Pontificia Universidad Javeriana, 2014.

Trouillot, Michel-Rolph. Peasants and Capital: Dominica in the World Economy. Baltimore: Johns Hopkins University Press, 1988.

Tucker, Joshua. 'From the World of the Poor to the Beaches of Eisha: Chicha, Cumbia, and the Search for a Popular Subject in Peru', in Cumbia!: Scenes of a Migrant Latin American Music Genre, ed. Héctor Fernández L'Hoeste and Pablo Sergio Vila. Durham, NC: Duke University Press, 2013. 138-67.

Tucker, Joshua. 'Peruvian Cumbia at the Theoretical Limits of Techno-Utopian Hybridity', in Experimentalisms in Practice: Music Perspectives from Latin America, ed. Ana R. Alonso-Minutti, Eduardo Herrera, and Alejandro L. Madrid. New York: Oxford University Press, 2018. 85-106.

Uribe Vergara, Jorge. 'Sociología biológica, eugenesia y biotipología en Colombia y Argentina (1918-1939)', in Genealogías de la colombianidad: formaciones discursivas y tecnologías de gobierno en los siglos XIX y XX, ed. Castro-Gómez Santiago and Eduardo Restrepo. Bogotá: Pontificia Universidad Javeriana, 2008. 204-221.

Valencia Rueda, Luis Fernando. 'The Alien Musical Brotherhood of the Colombian Andean Plateau: Sound Worlds, Musical Rhetoric, and Musical Meaning in Bogota's Experimental Tropical Psychedelia (1998- 2014)'. PhD diss., Princeton University, 2017.

Wade, Peter. Music, Race \& Nation: Música Tropical in Colombia. Chicago: University of Chicago Press, 2000.

Weheliye, Alexander G. Habeas Viscus: Racializing Assemblages, Biopolitics, and Black Feminist Theories of the Human. Durham, NC: Duke University Press, 2014.

Wynter, Sylvia. 'Unsettling the Coloniality of Being/Power/Truth/Freedom: Towards the Human, After Man, Its Overrepresentation - An Argument'. CR: The New Centennial Review 3/3 (2004), 257-337. 